\title{
CURRENT TRENDS IN BUSINESS COMMUNICATION: ANGLICISMS IN GERMAN
}

\author{
Alina BRUCKNER \\ Alexandru Ioan Cuza University of Iași, Romania
}

\begin{abstract}
Anglicisms have invaded all languages nowadays, but it seems that German is being invaded by English loanwords not only in oral but also in written communication. This article intends to briefly analyze whether Anglicisms represent an enrichment or rather an intrusion to a language, taking into consideration the fact that the influx of English loanwords upon German has even led to the appearance of a hybrid means of communication named Denglish. Examples of Anglicisms and pseudo-Anglicisms in German originate from an area that is nowadays mainly English, namely the business communication, more presicely advertising. But, apart from the linguistic considerations, Anglicisms are to be understood also as an expression of cultural, social, economic and even political aspects.
\end{abstract}

Keywords: Denglish, Anglicism, German language, advertising, cultural transfer.

\section{Introduction}

An Anglicism is to be defined as a word or construction borrowed from English into another language, or rather as a loanword, which is recognisably English in form, i.e. spelling, pronunciation or morphology. However, it encompasses much more, since what is borrowed is not only the word or construction, but also the culture itself. The adoption of Anglicisms implies therefore a cultural transfer, because not only the target language, but also the target culture is thus being changed. To what extent however is this change truly necessary?

\section{Anglicisms - Enrichment or Intrusion?}

Regarding the previously formulated rhethorical question, one might wonder whether an Anglicism can be seen as an enrichment or an intrusion, both from a 
linguistic, as well as from a cultural point of view. When trying to find the historical roots for the current spread of Anglicisms, one should not go further back than the 20th century, when due to the rise in Anglophone media and the spread of the British and mainly American cultures, many English terms have entered popular usage in other languages as well. Especially technology-related English words such as, for instance, internet or computer, are common in the entire world, since there were no pre-existing words for them in any other language.

In what concerns the process of the introduction of an Anglicism in a new language, several scholars agree that adaptation must first occur. In this respect, Roswitha Fischer distinguishes in her 2010 study Anglicisms in Europe: Linguistic Diversity in Global Context three phases of integration, as follows: The first step is named "the beginning", when the word is still new and not known to many people, being thus used in small circles or in very specific fields. In the second phase the word begins to spread and take part in the process of institutionalization, and finally in the third and final phase of integration, the word becomes part of the common core of the language (Fischer, 2010: 8).

Since nowadays English is the lingua franca, this vast spread of Anglicisms can be regarded as a normal phenomenon of language culture - in this regard, Aria Adli, a Linguistics professor at the University of Köln declared in an interview with Deutsche Welle that:

For the past few generations, English has had the prestige (of being seen) as cool, also thanks to the internet, movies and pop music, Before that, the French language had prestige (...) for a long time. Such fads are mirrored in the way we speak, it's natural. (Cords, 2019: DW.com)

Among the positive aspects brought about by the existence of a lingua franca one should mention the fact that due to the use of Anglicisms the intercultural communication and implicitly the international understanding become more efficient, under the widely acclaimed motto of "unity in diversity".

However, a declared UN goal is the preservation of languages and cultural diversity, having thus established an International Mother Language Day. As a result of the Anglicisation process, some languages are seen as being in danger of extinction nowadays. According to Bernhard Kettemann (Kettemann, 2002: 256) the share of loan words in the general vocabulary is very large in many languages, of up to $60 \%$. Certain national academies have even launched campaigns to stop the invasion of English upon the mother tongue. The Royal Spanish Academy, for instance, has recently adopted the motto "There's only one mother tongue", whereas the French Academy has an 
ongoing campaign to protect what is known as "the language of Moliere" against "the abusive borrowings from the English".

The Germans spotted a potential threat in the spread of Anglicisms as early as the end of the $19^{\text {th }}$ century: Hermann Dunger published in an 1899 article from Zeitschrift des Allgemeinen Sprachvereins the following opinion:

Along with the ever-growing influence of the English lifestyle, there has been an alarming increase in the number of redundant foreign words from English. In this linguistic phenomenon we again find a fundamental mistake: exaggerated admiration of everything foreign, lack of self-esteem, ignorance of one's mother tongue. (Kettemann, 2002: 256)

\section{Anglicisms in German - Denglish}

Needless to say, Anglicisms exert a rather significant influence upon German, as well. As mentioned by Plümer (2000: 28), since the $19^{\text {th }}$ century English has become the main donor language for German and due to the ongoing influx of Anglicisms used in German both in the language for specific purposes - which, from our point of view, to a certain extent, is somehow justifiable - and on a daily basis, lexical interference between the two languages increases. Some German linguists see a threat in the use of Anglicisms, suggesting that German may be in danger of becoming a peripheral language, whereas others consider that Anglicisms indicate openness to the world and language development.

Either way, linguists and specialists in the field distinguish between Anglicisms, Pseudo-Anglicisms and Denglish (the term may also be spelled according to the German rules, namely Denglisch). Anglicisms refer to those words which were adopted from the English language, because the German language had no expressions or equivalents for them. Typical examples for Anglicisms in German can be easily found in the world of computers and electronics, even though certain groups of German nationalists (including the NPD, i.e. the National Democratic Party of Germany) refuse to use English words, having translated them into German, such as the word Weltnetz instead of Internet or even Weltnetz-Seite instead of Website. Nonetheless, such words are considered to be exclusively the creation of the right extremists ${ }^{1}$ and do not even come up in German dictionaries.

Apart from the digital world, business-related topics and the mass media (especially in online versions) are more and more likely to be described nowadays in English than in German, mainly because of the globalization. For instance, it is rather common in many German-based companies nowadays to

\footnotetext{
${ }^{1}$ See the article Den Extremisten auf den Spur, published in Die Welt on $23^{\text {rd }}$ August 2000: https://www.welt.de/print-welt/article529570/Den-Extremisten-auf-der-Spur.html.
} 
refer to the boss as being the CEO, instead of Geschäftsführer or Vorstandsvorsitzender. In fact, titles like that - or perhaps, more appropriately formulated, English abbreviations - are used for the whole staff. And, by the way, staff is another example of an English word replacing the traditional German one, Belegschaft, which according to DUDEN is no longer widely used, being included nowadays in the $3^{\text {rd }}$ class of frequency use ${ }^{2}$.

Whereas Anglicisms seem to be necessary in German, PseudoAnglicisms, though probably more often used, have one specific feature: they resemble English (both in writing and in pronunciation), but they are completely made up. Famous examples of Pseudo-Anglicisms in German include the words Handy, which actually means mobile phone or Beamer, which means in fact video projector. Therefore, such Pseudo-Anglicisms may sometimes lead to serious misunderstandings, thus contradicting the positive aspect mentioned by the advocates of the use of Anglicisms, namely the international understanding achieved through an effective intercultural communication. For example, if a German mentions the possession of an Oldtimer, the native English speaker might get confused, thinking probably of a person; however, the German Oldtimer refers to a vintage car.

Any debate regarding the necessity of Anglicisms in German appears precisely because of such Pseudo-Anglicisms, which are in reality unnecessary and not in the least enriching. But the utmost expression of the excessive use of Anglicisms and Pseudo-Anglicisms in German is referred to as Denglish - a compound word formed from Deutsch and English. Defined by DUDEN as "a pejorative term for German with too many English expressions mixed in" (duden.de), Denglish may be regarded as the perfect illustration of the German language nowadays, some referring to it as a disease:

The German language suffers from a form of infectious disease, i.e. a raging Anglicitis. A mixed language is appearing, a strange means of communication, popularly named Denglish. Everywhere around us it is conquering our native vocabulary. ${ }^{3}$ (Heuermann, 2009: 293)

What is particularly criticized about Denglish is not only the tremendous wave of loanwords and invented words, but mainly the influence this phenomenon has upon the fundamental rules of grammar and pronunciation. Many Anglicisms developed first in the spoken language but after having

2 The online dictionary DUDEN classifies words in 5 classes depending on the frequency of their use. The $5^{\text {th }}$ class contains words that are very frequently used, whereas the $1^{\text {st }}$ class includes words rarely used in German.

https://www.duden.de/hilfe/haeufigkeit and https://www.duden.de/rechtschreibung/Belegschaft.

${ }^{3}$ My own translation from German into English. 
become part of the common core of the language they made their way into written communication. However, the English orthography of such words is often retained, which leads to strange spellings, combining German morphemes with English word stems, such as for instance "gecrasht" ("crashed" of a computer), "downgeloadet" or "gedownloadet" ("downloaded"). In many cases, some loanwords also retain the English phonology, including phonemes that do not exist in Standard German, such as $e i$ in "update". Especially when it comes to verbs, German grammar inflections are applied to English loanwords, which sometimes results in strange situations. German is now using the verb jobben ("to have a job", "to work"), resulted from the English noun "job" and the ending "-en" specific to infinitive verbs in German. Applying the conjugation scheme, the verb jobben takes new endings for each person, according to the German grammar rules.

Another form of Denglish consists of calques of popular English expressions, which replace German words and idioms. A common example, which is against German grammar rules, would be Das macht Sinn, a word-byword translation of the English phrase "That makes sense". Even though the correct German expression would be Das hat Sinn (i.e. "That has sense"), the Denglish form of the structure can be found nowadays both in oral and in written communication, such as the newspapers.

Denglish is also perceived when it comes to orthography, such as the use of the possessive construction 's, typical of English. A Denglish speaker might write "Anna's Haus" (Anna's house) instead of the correct German form "Annas Haus". Starting from here, another tendency seems to emerge, namely using the 's to mark a plural form, especially for abbreviations or loanwords, such as "Handy's", "LKW's", "PC's" or "GmbH's" instead of the correct German forms "Handys", "LKWs", "PCs" or "GmbHs".

\section{Anglicisms in German Advertising}

In the present world people are constantly confronted with advertisements, since they have basically invaded all spheres of life. In German, as well as in most other cultures, the language of advertising uses English words widely. Large national and international companies based in Germany use English to describe their services. For instance, the German television broadcaster ProSieben uses the slogan „We love to entertain you”. Other examples however include a mixture of English and German words, being thus emblematic for the Denglish phenomenon. Thus, Nivea uses the slogans: „Energy Creme Q10” and „Double Action Waschgel", to name just a few examples. The Microsoft Windows Update in German reads "Downloaden Sie die neuesten Updates!", which may

\footnotetext{
${ }^{4}$ Such incorrect forms are rather seldom used, especially in online articles.
} 
be considered another example of Denglish, since it conjugates the loanverb download and it capitalizes the noun updates, both according to German grammar rules.

One might even argue that, to a certain extent, English language in German advertising is not used, but abused, since a research conducted at the beginning of the 2000s revealed that no other European country has so many English advertisement slogans and campaigns as Germany (Kick, 2014: 1), the probable reason being the intention of companies to show a modern and innovative image. However, a survey conducted in Germany in 2003 by the company Endmark AG Köln showed that English words and slogans are fully understood by less than 50\% of German respondents (Kick, 2014: $67 \mathrm{ff}$.). Some famous examples of such misunderstandings are mentioned in an article published in 2008 in the online version of the newspaper Spiegel, according to which the slogan of Douglas perfume stores "Come in and find out" was misinterpreted by the Germans as "Come in, but then go back again". Beck's used to have the slogan "Welcome to the Beck's Experience". However, the slogan was not successful, since most Germans believed the last word meant "experiment".

Nonetheless, marketing and advertising strategies of German companies still rely heavily on the use of English loanwords, which is a result not only of globalization, but also of the changes in the German language caused by the influx of Anglicisms and Denglish. In fact, specialists in the field of advertising argue that English slogans are easier to remember and convey positive features, even if they are not fully understood (Kick, 2014: 79).

\section{Conclusions}

The debate whether Anglicisms are enriching or intrusive is probably everlasting, as well as the question regarding the extent to which Anglicisms should be used in a particular language. Nevertheless, the prolific wave of Anglicisms nowadays is symptomatic not only of the fact that English is indeed the lingua franca, but also of the political, social and economic aspects that despite all differences unite us all. In the year 2010 a team of linguists lead by Anatol Stefanowitsch, a professor at Freie Universität Berlin, came up with the initiative Anglizismus des Jahres, i.e. to vote each year the most influential Anglicism in the German language. All the Anglicisms chosen so far clearly reveal their social, economic and political impact upon the German culture. To name just a few examples, the Anglicism of the year 2010 was leaken, of the year 2015 Refugees Welcome and of the year 2016 Fake News. 


\section{Works Cited}

Cords, S., Anglicisms are natural, but language diversity still essential, DW.com, 21.02.2019. Web.

Fischer, R., and Hanna Pulaczewska, Anglicisms in Europe: Linguistic Diversity in Global Context, Cambridge, Cambridge Scholars Publishing, 2009.

Heuermann, H., Mythos. Religion. Ideologie: kultur- und gesellschaftskritische Essays, Frankfurt am Main, Peter Lang, 2009.

Kettemann, B., „Anglicisms in German: Enrichment or Intrusion?” in AAA: Arbeiten aus Anglistik und Amerikanistik, 27.2, 255 - 271, Tübingen, Narr Francke Attempto, 2002.

Kick, I., Die Wirkung von Anglizismen in der Werbung: „Just do it” oder lieber doch nicht?, Hamburg, Diplomica, 2014. Web.

Kimmerle, B., Den Extremisten auf der Spur, WELT.de, 23.08.2000. Web.

Plümer, N., Anglizismus - Purismus - Sprachliche Identität. Eine Untersuchung zu den Anglizismen in der deutschen und französischen Mediensprache, Frankfurt am Main, Peter Lang, 2000.

Schmitz, M., Anglicisms and Pseudo Anglicisms in Germany. Lass Deutsch talken, thoughtco.com, 06 March 2017. Web.

Stefanowitsch, A., Anglizismus des Jahres, anglizismusdesjahres.de. Web.

*** How Germans Really See German Ad Slogans, SPIEGEL.de, 12.12.2008. Web. DUDEN.de

\section{BIONOTE}

ALINA BRUCKNER is a Lecturer, PhD, at the Faculty of Economics and Business Administration from Iasi, is specialized not only in Business German, but also in intercultural communication, with a focus on German culture. She is the author of several articles published in international journals, as well as of a book focusing on mass literature, published in Hamburg, Germany. Furthermore, she has recently translated Ludwig von Mises's Kritik des Interventionismus (Critique of Interventionism) from German into Romanian, currently working on the translation of Franz Oppenheimer's Der Staat (The State).

Email: bruckner.alina@gmail.com 
